\title{
НОВЫЕ СОЕДИНЕНИЯ ДЛЯ БОР-НЕЙТРОНОЗАХВАТНОЙ ТЕРАПИИ РАКА
}

\author{
В.И. Брегадзе \\ Лаборатория алюминий-и борорганических соединений, \\ Институт элементоорганических соединений им. А.Н. Несмеянова РАН, \\ 119991, Россия, Москва, ул. Вавилова, д. 28
}

DOI: 10.19163/MedChemRussia2021-2021-116

E-mail: bre@ineos.ac.ru

Соединения, пригодные для бор-нейтронозахватной терапии (БНЗТ) рака, должны обладать способностью к избирательному накоплению в клетках злокачественных опухолей. Такая избирательность может осуществляться путёмполучения конъюгатов борсодержащих молекул с молекулами, склонными к избирательному связыванию с клетками раковых опухолей, так называемые «tumor-seeking» молекулы. Ранее были рассмотрены типы таких молекул [1].

В данной работе будут представлены последние результаты по синтезуконъюгатов полиэдрических соединений бора с некоторыми порфиринами и по получению борсодержащих липосом. Впервые получен и охарактеризован конъюгатаминоамида хлорина е с с бис(дикарболлидом) железа и исследованы его биологические свойства на культуре клеток глиобластомы крысы С6[2]. Взаимодействием бис(дикарболлида) кобальта и других производных карборановс холестеролами получены конъюгатыс целью дальнейшегоихпревращения в борсодержащие липосомы [3,4]:
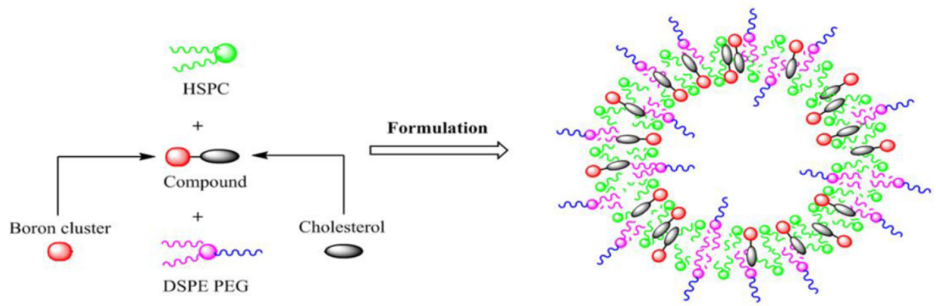

Работа выполнена при поддержке Российского фонда фундаментальных исследований (грант № 19-03-00255)

\section{Литература}

[1]I.B. Sivaev, V.I. Bregadze, Eur. J. Inorg. Chem., 2009, 1433-1450.

[2]A.A. Ignatova, Yu.S. Korostey, M.K. Fedotova, I.B. Sivaev, V.I. Bregadze, A.F. Mironov, M.A. Grin, A.V. Feofanov, FutureMed. Chem., 2020, 12, 1015-1023.

[3] V.I. Bregadze, I.B. Sivaev, R.D. Dubey, A. Semioshkin, A.V. Shmal'ko, I.D. Kosenko, K.V. Lebedeva, S. Mandal, P. Sreejyothi, A. Sarkar, Z. Shen, A. Wu, N.S. Hosmane, Chemistry-AEuropeanJournal, 2020, 26, 13832-13841.

[4] A. Druzina, O. Zhidkova, N. Dudarova, I. Kosenko, I. Ananyev, S. Timofeev and V. Bregadze, Molecules, 2021, 26, 530-545. 